\title{
DARI LITURGI BAPTISAN MENUJU LITURGI KEHIDUPAN: Menjadi Gereja bagi Perempuan Korban Kawin Tangkap
}

\section{Irene Umbu Lolo}

\author{
Pendeta Gereja Kristen Sumba dan Dosen STT GKS \\ Jl. Pametikarata-Lewa, Kab. Sumba Timur, NTT \\ ireneumbulolo@gmail.com
}

\begin{abstract}
This article is a feminist liturgical imagination that aims to provide a recoveryspace for women victims of sexual violence. With the background of women experience as victims of marriage by abduction, this paper presents imaginative theological thoughts using the views of Ruether and Berger in the framework of providing an ecclesiastical ritual in favor of women victims.The church must stand with women victims of sexual violence. The support of the church can be shown through the provision of a liturgical space where women victims can share their experiences and at the same time reclaim one of the important symbols in the Christian liturgy, namely water as a sacred symbol of restoration. This ecclesiastical ritual is a space for women victims to show reversal movements, from circumstances and events where water marks past experiences of violence, to circumstances and events where water marks the present and future experience of healing.
\end{abstract}

Keywords: women, marriage by abduction, baptism, water, liturgy

\begin{abstract}
Abstrak
Tulisan ini merupakan suatu imajinasi liturgi feminis yang bertujuan menyediakan ruang pemulihan bagi perempuan korban kekerasan seksual. Dengan dilatari oleh pengalaman korban kawin tangkap,tulisan ini menyuguhkanpemikiran imajinatif teologis dengan menggunakanpandangan Ruetherdan Berger dalam kerangka menyediakan suatu ritual gerejawi yang berpihak pada perempuan korban.Gereja mesti berdiri bersama perempuan korban kekerasan seksual. Keberpihakan gereja itu dapat ditunjukkan melalui penyediaan ruang liturgis dengan mana perempuan korbandapat membagi pengalamannya sekaligus mengklaim kembali salah satu simbol penting dalam liturgi Kristen yaitu air sebagai simbol sakral yang memulihkan. Ritual gerejawi ini merupakan ruang bagi perempuan korban untuk menunjukkan gerakan berbalik arah, dari keadaan dan peristiwa di mana air menandai pengalaman kekerasan di masa lampau, menuju keadaan dan peristiwa di mana air menandai pengalaman pemulihan di masa kini dan masa yang akan datang.
\end{abstract}

Kata kunci: perempuan, kawin tangkap, baptisan, air, liturgi 


\section{PENDAHULUAN}

Peristiwa kekerasan seksual masih sering terjadi dalam masyarakat. Perempuan kerap menjadi korban dari tindakan tersebut. Konstruksi sosial budaya masyarakat patriarkat yang mengutamakan laki-laki tak jarang menempatkan perempuan sebagai kelompok marginal yang rentan mengalami berbagai bentuk kekerasan berbasis gender.

Tulisan ini diawali dengan penjelasan tentang pengalaman perempuan korban kawin tangkap (selanjutnya disingkat KT) sehingga pembaca memperoleh gambaran tentang salah satu persoalan kekerasan seksual yang menimpa perempuan khususnya di Pulau Sumba, Nusa Tenggara Timur. Setelah memaparkan pengalaman korban KT, tulisan ini kemudian menunjukkan dampak negatif dari praktik itu terhadap para korban bahkan perempuan pada umumnya. Pada bagian akhir, tulisan ini berbicara tentang pentingnya tindakan pemulihan bagi perempuan korban KT. Dengan menggunakan pemikiran Ruether dan Berger, tulisan ini menawarkan suatu liturgi yang dapat digunakan oleh umat beriman dalam rangka memberikan dukungan kepada perempuan korban KT agar kembali pulih.

KT yang marak terjadi di Sumba, merupakan salah satu bentuk kekerasan seksual yaitu pemaksaan perkawinan terhadap perempuan. Tindakan itu dilakukan oleh laki-laki terhadap perempuan yang diingininya untuk dijadikan istri. Tindakan penangkapan atau penculikan itu dilakukannya di tempat umum atau di tempat yang ramai seperti di pasar, di jalan, di pesta-pesta adat, di tempat menimba air, juga di rumah orang tua korban atau di rumah keluarga korban. KT sering dipraktikkan di ruang publik sebagai bentuk pertunjukkan aksi "kejantanan" laki-laki pelaku terhadap perempuan korban, juga untuk menunjukkan kepada publik "kemenangan" dan "prestasi"-nya sebagai laki-laki perkasa. ${ }^{1}$

Pelaku KT dalam melaksanakan aksinya dibantu oleh sekelompok laki-laki. Mereka akan mendatangi perempuan yang menjadi target, menangkapnya, dan membawanya secara paksa ke rumah pelaku. Latar belakang perempuan yang ditangkap bervariasi mulai dari usia masih belia, tidak sekolah, dan tidak punya pekerjaan, sampai pada usia dewasa, sarjana, dan bekerja di kantor. Berdasarkan 
hasil penelitian, praktik yang dilegitimasi secara kultural ini dilakukan oleh seorang laki-laki terhadap perempuan yang diinginkannya baik yang masih ada hubungan kekeluargaan dengannya (anak paman), maupun yang tidak ada hubungan kekeluargaan secara langsung. Perempuan yang ditangkap umumnya tidak mengetahui rencana penangkapan itu dan tidak mengingini atau mencintai laki-laki pelaku. Ada juga perempuan korban yang sama sekali tidak mengenal laki-laki yang menangkapnya. Itulah sebabnya perempuan korban umumnya menolak, berontak, dan berusaha melepaskan diri dari cengkeraman laki-laki yang menangkapnya. Akan tetapi mereka sering kali tidak dapat melepaskan diri dan tidak memperoleh pertolongan dari orang lain yang menyaksikan peristiwa penangkapan itu. Perempuan korban yang menangis dan berteriak minta tolong sering kali tidak dihiraukan oleh masyarakat. Sebagian besar masyarakat Sumba masih beranggapan bahwa KT adalah praktik budaya yang wajar dan biasa. ${ }^{2}$

Kultur masyarakat patriarkat di Sumba memfasilitasi dan mendukung lakilaki pelaku dalam melancarkan aksinya menangkap perempuan. Sekalipun banyak pihak di Sumba enggan mengakui bahwa KT adalah bagian dari budaya Sumba, namun dalam buku "Masyarakat Sumba dan Adat-istiadatnya" secara jelas dinyatakan bahwa KT merupakan Piti Maranggangu (ambil dalam pertemuan) sebagai salah satu cara perkawinan tanpa melamar. ${ }^{3}$ Itu artinya KT merupakan bagian dari budaya Sumba yang dipraktikkan oleh masyarakat secara berulang. Pelaku KT bahkan selalu menggunakan instrumen budaya sebagai alat pembenaran atas tindakannya tersebut. Pelaku biasanya akan menempuh cara adat setelah berhasil menangkap perempuan. Ia dan keluarganya akan datang menjumpai orang tua korban dengan membawa hewan belis untuk "minta maaf" dan membayar denda adat. Jika hewan diterima, maka persoalan dianggap selesai dan negosiasi adat dilanjutkan sampai ke jenjang pernikahan. Keseluruhan prosesi budaya ini memosisikan perempuan korban sebagai objek negosiasi dan pihak yang wajib menaati semua keputusan keluarga baik keluarga pelaku maupun keluarganya sendiri. 


\section{METODE}

Artikel ini berusaha untuk menampilkan pengalaman perempuan Sumba yang menjadi korban dari praktik KT menggunakan metode penelitian kualitatif deskriptif. Objek kajian penelitian ini adalah teks sekaligus pengalaman perempuan Sumba, kemudian dikaji dengan berbagai literatur feminis-teologis. Untuk mengurai pengalaman perempuan itu, maka artikel ini melihat pengalaman perempuan sebagai subjek yang hidup dan berbicara dalam konteksnya, terutama dalam gereja.

\section{PEMBAHASAN}

Praktik KT secara nyata berakibat buruk pada perempuan korban. Praktik ini merupakan teror bagi perempuan Sumba tidak saja korban, tetapi juga kaum perempuan pada umumnya. Kejahatan KT yang menimpa perempuan dari beragam latar belakang itu menimbulkan trauma kolektif yaitu rasa takut, terancam, dan tidak aman di kalangan perempuan Sumba. Para pendamping korban di lapangan juga tak luput dari intimidasi dan secondary trauma.

Praktik KT ini merupakan kejahatan kemanusiaan yang mengakibatkan perempuan korban mengalami kekerasan berlapis yaitu kekerasan fisik (dipegang, ditarik, dicengkeram, disekap, dikurung), kekerasan psikis (merasa trauma, tertekan, terancam, terhina, dilecehkan, tidak berharga, sedih, marah, malu), kekerasan seksual (bagian tubuh tersingkap, dipegang, diperkosa), dan kekerasan sosial (perempuan yang melarikan diri dari rumah pelaku distigma oleh masyarakat sebagai perempuan yang "sudah kena cap" dan "telah ternodai"). Pengalaman kekerasan itu menyebabkan mereka sakit dan trauma dalam kurun waktu yang sangat lama.

Praktik KT secara nyata merupakan bentuk pelanggaran HAM Perempuan. Hak-hak dasar perempuan korban untuk berbicara dan didengarkan tidak diindahkan oleh orang lain terutama oleh pelaku dan keluarganya. Hak asasinya untuk hidup bebas tanpa intimidasi telah direnggut dari dirinya. Kekerasan KT merupakan bukti bahwa perempuan tidak bebas untuk menjalani kehidupan sendiri dan menentukan pilihan atas masa depan mereka sendiri. KT terbukti memosisikan perempuan seperti 
barang atau objek negosiasi dan bukan subjek (manusia) yang dihargai dan didengarkan pendapat dan keinginannya.

Secara teologis dapat dinyatakan bahwa KT adalah perbuatan yang mengingkari martabat perempuan sebagai manusia yang diciptakan menurut gambar Allah. KT yang dilegitimasi oleh budaya patriarkat itu secara nyata telah merendahkan nilai seksualitas perempuan sebagai suatu esensi tubuh yang melaluinya ia memperoleh pengertian tentang Allah. KT adalah suatu tindakan yang merusak potensi perempuan untuk memelihara relasi intim dengan Allah melalui seluruh keberadaan dan pengalamannya menubuh. ${ }^{4}$

\section{Air dalam Pengalaman Perempuan Korban KT}

Berikut ini akan dijelaskan bagaimana air dipakai oleh pelaku dan keluarganya untuk meruntuhkan pertahanan perempuan korban. Air yang merupakan salah satu unsur ritual dalam agama suku Sumba, oleh pelaku dan keluarganya dipakai sebagai senjata yang diyakini mengandung kekuatan supranatural yang dapat mematahkan perlawanan perempuan korban KT.

Setibanya di rumah pelaku, perempuan korban biasanya disirami atau diperciki air terutama di bagian wajah dan kepala. Perempuan korban sering kali kesulitan untuk menghindari siraman atau percikan air tersebut karena masih dalam kondisi dipegang oleh sekelompok laki-laki. Meskipun demikian, ada juga perempuan korban yang dapat menghindari air itu. Ironisnya, tindakan menyiram air umumnya dilakukan oleh perempuan yang dituakan dalam keluarga pelaku antara lain ibu dari pelaku. Nyata di sini bagaimana perempuan Sumba bukan saja rentan menjadi korban kekerasan, melainkan juga rentan dipakai sebagai alat untuk mendukung praktik kekerasan tersebut. Perempuan dikondisikan sebagai pendukung tindakan kekerasan seksual terhadap perempuan.

Air merupakan media penting dalam ritual Agama Marapu (agama Suku Sumba). Ritual Hawari atau ritual Habarangu adalah ritual yang dilakukan untuk membersih diri, ternak, dan alam atau lingkungan sekitar. Ritual Hawari dilakukan di dalam rumah sedangkan ritual Habarangu dilakukan di luar rumah yaitu pada tempat-tempat keramat (pahomba). Rato (Imam Marapu) akan mengambil air dingin 
dan meletakkannya di dalam wadah tempurung kelapa. Ia mengucapkan kalimat doa untuk memberkati air tersebut. Kemudian dengan menggunakan dedaunan (antara lain daun kemangi), ia memercikkan air itu pada manusia dan ternak di dalam rumah, termasuk tempat tidur. Ia juga memercikkan air tersebut di halaman rumah dan di sekitar pemukiman warga kampung. Upacara yang sama juga terjadi di pahomba atau tempat-tempat keramat. Keseluruhan upacara itu bertujuan untuk membersihkan, menyucikan, dan memberkati manusia, ternak, dan tempat-tempat yang dianggap telah tercemar. Ritual ini juga bertujuan untuk mendinginkan dan memberkati orang, ternak, dan tempat-tempat yang dianggap panas. ${ }^{5}$

Ritual memercikkan air juga dipraktikkan oleh keluarga laki-laki terhadap perempuan (anak mantu) dalam upacara perkawinan adat. Setelah seluruh percakapan adat selesai, perempuan akan berpindah dari rumah orang tuanya ke rumah orang tua suaminya menurut tata cara adat. Sebagaimana lazimnya, di depan pintu masuk rumah orang tua suaminya, perempuan itu akan disambut dan dipercikkan air dingin oleh ibu mertuanya atau perempuan lain yang dituakan dalam keluarga suaminya. Percikan air ini bertujuan untuk memberkati anak mantu.

Pelaku KT dan keluarganya mengadopsi ritual sakral dalam konteks Agama Marapu dan prosesi percik air berkat dalam upacara perkawinan adat ini dengan atensi yang berbeda, sekalipun menggunakan media yang sama yaitu air. Tujuan mereka memercikkan air bukan untuk memberkati, melainkan untuk membungkam perempuan korban. Perempuan korban yang berontak dan marah dianggap sebagai makhluk yang panas dan membahayakan. Oleh karena itu, ia mesti didinginkan dan “dijinakkan”. Suara tangisannya sebagai korban dianggap mengganggu sehingga perlu segera didiamkan melalui percikan atau siraman air di wajah dan kepala. Jika air dalam Ritual Marapu merupakan simbol penyucian dan pemulihan, maka air dalam peristiwa KT merupakan simbol penindasan dan penaklukan. Jika air dalam Ritual Marapu dan dalam upacara perkawinan merupakan simbol untuk memberkati, maka air dalam peristiwa KT merupakan simbol untuk menyerang dan menguasai perempuan. 
Dalam praktik KT, air memiliki konotasi yang negatif. Air dipakai oleh pelaku dan keluarganya sebagai alat intimidasi dan penyiksaan. Sebagaimana telah disebutkan, pelaku menggunakan air sebagai media untuk menyerang, "mendinginkan", dan "menjinakkan" korban. Oleh karenanya air tersebut dihindari oleh korban. Dalam pengalaman perempuan korban, air tersebut merupakan simbol yang menakutkan dan menimbulkan trauma. Air yang merupakan unsur alam yang sangat dekat bahkan menyatu dengan diri perempuan, kini dalam konteks KT menjadi unsur yang dihindari dan ditakuti. Itulah sebabnya perempuan korban berjuang sebisa mungkin untuk menghindari air percikan karena bisa berdampak negatif pada diri mereka, sekalipun hal itu tidak mudah. Berdasarkan pengalaman perempuan yang kemudian berhasil lolos dan melarikan diri dari rumah pelaku, mereka umumnya berupaya agar air itu tidak menyentuh wajah mereka.

Air dalam kepercayaan Marapu dipakai sebagai metafora untuk menggambarkan keberadaan Alkhalik yang pantang disebutkan nama dan gelar-Nya. Ia dipercakapkan dengan menggunakan metafora air. Alkhalik disapa dalam bahasa Sumba sebagai Na Pingi Ai Luri-Na Mata Wai Torungu yang artinya Pokok Kayu Hidup-Sumber Air Hidup. Orang Sumba memahami Alkhalik sebagai sumber keselamatan, kesejahteraan, dan kebahagiaan kekal. Ia merupakan sumber air yang menghidupkan tidak saja bagi manusia, tetapi juga bagi hewan, tanaman, dan seluruh ciptaan. Air menjadi benda simbolis yang menggambarkan hakikat Alkhalik yang mendatangkan keselamatan, kesejahteraan, dan kebahagiaan kekal. ${ }^{6}$

Selain itu, air juga dipakai sebagai metafora untuk berbicara tentang bumi dan tanah yang dihubungkan dengan perempuan. Orang Sumba menggambarkan bumi dan tanah ini ibarat ibu yang menyusui dan menghidupkan. Dalam bahasa Sumba disebut: Na maka pudata la pari peku-na mapa hu huta la kalelu langga, artinya ibu yang merawat dan memelihara dengan nasi yang layak dan menyusui laksana pepaya manis. Tanah yang terhubung dengan air dipandang merupakan sumber kehidupan seluruh makhluk. Air hujan yang tercurah dari langit diyakini sebagai air susu ibu yang diperah dari langit. Dalam bahasa Sumba diungkapkan: $\mathrm{Na}$ ma pohu maliru-ma pahulu marau, artinya yang memerah dari jauh-yang menyusui dari jarak jauh. Air hujan dilihat sebagai air sumber kehidupan yang dianugerahkan 
Tuhan yang merupakan Ibu Yang Baik yang memelihara seluruh ciptaan-Nya di bumi. $^{7}$

Akan tetapi dalam praktik KT, nilai filosofis yang penting ini dijungkirbalikkan oleh pelaku dan komplotannya. Air tidak lagi menggambarkan nilai-nilai luhur sebagaimana telah disebutkan. Bagi perempuan korban KT, air berubah menjadi sumber malapetaka, kesakitan, dan penderitaan. Air merupakan benda simbolis yang melemahkan, melumpuhkan, dan membekukan dirinya sebagai korban. Air tidak lagi menjadi sumber kekuatan dan kehidupan bagi korban, tetapi sebagai sumber yang melemahkan dan mematikan. Air berubah kapasitas dan maknanya secara simbolis bagi korban. Ia bukan lagi unsur yang dicari dan diharapkan untuk bertahan hidup, melainkan benda simbolis mengerikan yang harus dihindari oleh korban agar tetap kuat dan selamat.

\section{Metanoia sebagai Tindakan Berbalik Arah}

Rosemary Radford Ruether seorang teolog feminis dari Garrett-Evangelical Theological Seminary-Amerika, menyebutkan pentingnya tindakan berbalik arah (metanoia) bagi perempuan penyintas kekerasan. Dalam bukunya yang berjudul "Women-Church, Theology and Practice of Feminist Liturgical Communities", ia menjelaskan tentang metanoia yang dihubungkannya dengan baptisan. Ia menyatakan bahwa baptisan merupakan penanda dari proses berpaling atau berbalik arah tersebut. "We should than think of our baptism as the process of metanoia or turning around by which we see through the ideologies of alienated life and get in touch with the original blessing, which is the true ground of our being." 8

Menurut Ruether, umat berpaling atau berbalik arah terutama dari prinsip dan kekuatan penindasan personal dan sistemik. Baptisan menjadi tanda yang kelihatan dari pilihan sikap umat yang secara sadar menolak berbagai bentuk kuasa patriarki yang menindas, yang terekspresi di dalam sistem sosial, ekonomi, politik, budaya, bahkan sistem bergereja. Bagi Ruether, umat bukan saja secara personal menolak kekuasaan yang menindas di dalam hati dan pikiran, melainkan juga secara bersama- 
sama sebagai satu persekutuan mematahkan cengkeraman kekuatan ini di dalam kehidupan komunitas. ${ }^{9}$

Lebih jauh Ruether menjelaskan tentang teologi baptisan yang memiliki sisi objektif dan subjektif. Sisi objektif dari baptisan yaitu kasih karunia Allah yang membebaskan. Anugerah Allah itu merupakan sumber kekuatan bagi umat untuk berpaling dari penindasan. Makna penting baptisan terletak di sini yaitu bahwa anugerah Allah telah membebaskan umat dan memberi mereka kapasitas untuk berbalik arah atau keluar dari kungkungan sistem kuasa kejahatan yang menindas. Proses umat menerima anugerah Allah dan membuat perjalanan berbalik arah itu merupakan sisi subjektif dari baptisan. Proses berbalik arah itu bermakna personal dan membawa umat pada pengalaman konversi atau perubahan secara radikal. ${ }^{10}$

Sehubungan dengan percakapan tentang metanoia, Ruether berbicara mengenai konversi atau perubahan radikal sebagai suatu pilihan sikap. Ia menjelaskan pandangannya tentang pentingnya konversi sebagai suatu tindakan memutus rantai pengasingan dan penindasan yang telah merusak kesadaran umat, yang membuat umat menerima pengalaman penindasan itu sebagai hal yang normal dan wajar. Menurut Ruether, umat secara keseluruhan terlanjur diindoktrinasi secara turun-temurun di dalam pola-pola budaya yang membenarkan sistem patriarki dan membuat sistem yang menindas tersebut tampak sebagai sesuatu yang natural dan dikehendaki Allah. Oleh karenanya bagi Ruether, tindakan konversi mesti menjadi pilihan sikap. Konversi merupakan suatu lompatan ke arah kesadaran baru untuk menolak semua ideologi yang menindas dan menemukan dunia alternatif di mana kehidupan dan relasi yang setara menjadi pengalaman nyata. ${ }^{11}$

Percakapan Ruether tentang metanoia sebagai suatu ekspresi ritual pada satu sisi dihubungkan dengan pengalaman orang dewasa. Baptisan sebagai keputusan perubahan kesadaran tentang patriarki tersebut diekspresikan oleh orang dewasa. Sekalipun demikian, menurut Ruether hal itu tidak berarti bahwa anak-anak tidak bisa dilibatkan dalam ritual ini. Pada sisi yang lain, anak-anak yang lahir dari komunitas umat beriman, melalui dan bersama orang tuanya, dapat menyatakan komitmen dan tekad yang sama yaitu meninggalkan berbagai bentuk kejahatan patriarki. Bagi Ruether, ritus baptisan yang dipersatukan dengan ritus memberi nama 
pada anak atau orang yang dibaptis itu dilakukan sebagai wujud penegasan tentang perjalanan menuju kehidupan baru dan kebebasan yang hakiki. ${ }^{12}$

Sehubungan dengan pengalaman perempuan korban KT, pemikiran Ruether ini dapat menjadi pintu masuk untuk mendesain suatu aksi pembebasan yang dikemas secara liturgis. Konversi merupakan aspek yang penting dalam kehidupan perempuan korban KT. Mereka mesti berada dalam komunitas yang berdiri bersama mereka untuk menyatakan tindakan perubahan atau berbalik arah tersebut. Melalui aksi liturgis, mereka menolak dan memutus rantai kekerasan dan penindasan yang mewujud dalam KT. Mereka bersama komunitas pendukung secara terencana berada dalam suatu momen sakral untuk bersikap dan menunjukkan lompatan ke arah kesadaran baru yang menolak ideologi budaya patriarki di Sumba yang diskriminatif serta menemukan dunia atau tatanan kehidupan baru yang lebih adil dan setara.

Hal penting yang ditawarkan dari pemikiran Ruether ini adalah bagaimana pemaknaan terhadap ritual baptisan dapat membantu umat untuk bersama perempuan korban KT melihat dimensi membebaskan dari ritual gerejawi tersebut. Bahwa baptisan yang umat alami bukanlah suatu ritual kosong tanpa makna, melainkan suatu momentum di mana umat mengalami anugerah Allah yang membebaskan dan membuat mampu mereka untuk mewujudkan metanoia dan konversi. Dalam hal perempuan korban/penyintas KT, pengenangan atas peristiwa baptisan melalui penggunaan media air merupakan momentum dengan mana anugerah Allah yang membebaskan itu diingat dan diklaim kembali sekaligus dijadikan daya dorong untuk berbalik arah. Perempuan korban KT berbalik arah dari pengalaman kehidupan lama yang diwarnai oleh penindasan dan kekerasan ke pengalaman kehidupan baru yang diwarnai oleh pemulihan dan pembebasan. Aksi liturgis yang dilakukan memiliki makna strategis yaitu pernyataan tekad perempuan korban/penyintas untuk bangkit, bergerak, dan memasuki tahapan kehidupan yang baru.

Penulis tidak bermaksud untuk menyatakan bahwa para penyintas mesti dibaptis ulang. Tetapi penulis hendak menjadikan pengalaman akan baptisan dan air sebagai titik berangkat untuk melihat dan mengklaim kebebasan yang telah dianugerahkan Allah kepada umat. Percakapan tentang teologi baptisan membuka 
ruang bagi umat untuk mendesain suatu aksi liturgis yang berciri membebaskan. Hal itu dimulai dari percakapan mengenai teologi baptisan yang secara khusus memberi perhatian pada pengalaman perempuan dan air sebagai unsur penting.

\section{Liturgi Berbasis Pengalaman Perempuan}

Teresa Berger, seorang teolog feminis-liturgis dari Duke Divinity SchoolAmerika, berbicara mengenai liturgi yang dihubungkan dengan kehidupan perempuan. Ia sebagaimana Ruether, menuliskan pandangannya tentang liturgi dari sudut pandang dan pengalaman perempuan. Sekalipun ia menyadari bahwa kehidupan liturgikal gereja tradisional terbukti mengasingkan perempuan bahkan membenturkannya dengan pengalaman perempuan, ia tetap teguh untuk mengklaim tradisi liturgikal sebagai situs iman dan hikmat perempuan. Pandangannya itu ia dasarkan pada tiga alasan utama. Alasan pertama, menurutnya, sampai detik ini perempuan secara kontinu dan nyata hadir di dalam liturgi gereja. Jumlah perempuan yang hadir dalam ibadah melebihi jumlah laki-laki. Alasan kedua, bahwa liturgi bagi perempuan merupakan situs yang sangat kaya yang memberi makna, kekuatan, dan kelegaan bagi perempuan. Melalui liturgi, perempuan mengalami perjumpaan dengan hadirat Allah yang menghidupkan. Alasan ketiga, menurutnya, liturgi tetap penting bagi perempuan yaitu untuk menumbuhkan dan mempertajam kepekaan spiritualnya melalui perjumpaannya dengan Allah setiap hari. ${ }^{13}$

Berger menggunakan istilah concelebration untuk menggambarkan keterkaitan antara liturgi dengan pengalaman perempuan. Bagi Berger, liturgi dan kehidupan perempuan itu tak terpisahkan dan merupakan suatu konselebrasi atau perayaan bersama. Perempuan bersama umat beriman terlibat aktif dalam mencari dan menemukan makna liturgikal dalam kehidupan mereka sehari-hari. Proses membuat makna liturgikal itu tidak berhenti di dalam ruang ibadah tetapi terus berlanjut dalam kehidupan di luar ruang ibadah. Di sinilah makna liturgi sebagai suatu konselebrasi. Perempuan dan umat beriman menemukan makna liturgikal dalam realitas kehidupan yang konkret dengan beragam kondisi kehidupan dan pengalamannya masing-masing. ${ }^{14}$ 
Secara sangat spesifik dalam bukunya yang berjudul Fragments of Real Presence, Liturgical Traditions in the Hands of Women, Berger mengajak pembaca untuk memaknai baptisan berdasarkan pengalaman perempuan. Menurutnya, melalui ritual baptisan umat dapat memahami Allah yang tidak meniadakan pengalaman perempuan, melainkan yang mengintegrasikan karya penyelamatan-Nya ke dalam kehidupan dan pengalaman perempuan. Bagi Berger, umat dapat mengimajinasikan Allah yang berkata: "Sama seperti engkau perempuan, demikianlah Aku perbuat. Sama seperti engkau memelihara kehidupan di dalam tubuhmu, demikian pula Aku memberi dan memelihara kehidupan di dalam tubuh-Ku yakni gereja." ${ }^{15}$

Berger menyatakan bahwa umat dapat menemukan jejak kesesuaian antara kehidupan perempuan dan karya penyelamatan Allah. Jejak itu ada pada sakramen baptisan yang di dalamnya tertanam gambaran kelahiran. Menurutnya, kata rachamim pada teks Alkitab bahasa Ibrani yang menunjuk pada kemurahan Allah itu, memiliki akar kata yang sama dengan rechem (rahim). Dari sini, umat dapat memahami bahwa penebusan Allah sama seperti rahim seorang ibu merupakan suatu pelukan yang memberi hidup. Baptisan dapat dilihat sebagai suatu ekspresi keibuan Allah yang memeluk dan memberi hidup. Rahim perempuan merupakan suatu metafora yang kuat untuk memahami realitas Allah yang menciptakan dan menganugerahi kehidupan. ${ }^{16}$ Itulah sebabnya dalam beberapa refleksi teologis disebutkan gambaran sakramen baptisan sebagai rahim gereja yang dianugerahi dan dibuahi oleh Roh Allah. Begitu pula bejana baptisan yang didesain dalam bentuk rahim. ${ }^{17}$ Semuanya itu untuk menegaskan bahwa ada kesesuaian antara rahim perempuan dan baptisan sebagai wujud kemurahan hati Allah yang menghidupkan dan menyelamatkan.

Berger menyayangkan liturgi gereja yang justru telah meminggirkan atau menegatifkan pengalaman perempuan yang spesifik ini. Gereja menampilkan liturgi dengan pengalaman perempuan, antara kelahiran dan kelahiran kembali, antara air ketuban dan air baptisan, antara penciptaan dan penebusan. Menurutnya, tradisi Kristen terbukti merendahkan tubuh perempuan dan kekuatan mereka untuk melahirkan kehidupan. Itulah sebabnya ritual gerejawi yang dilakukan sehubungan 
dengan masa kehamilan dan kelahiran hanya untuk menandai bahwa pada masa tersebut perempuan berada dalam kondisi najis. ${ }^{18}$

Kritik Berger benar adanya. Peminggiran dan penegatifan pengalaman perempuan itu antara lain tampak pada liturgi gereja yang menggunakan metafora tubuh dan pengalaman perempuan dalam konotasi yang negatif. Formula liturgi baptisan gereja yang mencantumkan pernyataan tentang rahim atau kandungan perempuan sebagai tempat dosa bercokol. Salah satu pertanyaan liturgis yang diajukan kepada orang yang dibaptis atau orang tua yang anaknya dibaptis adalah: "Mengakukah saudara/saudari bahwa engkau atau anakmu telah tercemar dengan dosa sejak dalam kandungan?" . Rumusan pertanyaan ini secara jelas menunjukkan bagaimana tubuh dan pengalaman perempuan atas rahimnya dimaknai secara negatif. Dari sanalah dosa bertumbuh dan dilahirkan. Rahim perempuan adalah tempat dosa dikandung. Di sini nyata bahwa liturgi gereja tidak memberi ruang pada pemaknaan positif tentang rahim dan pengalaman perempuan pada saat melahirkan sebagai peristiwa sakral yang mirip dengan proses baptisan itu sendiri yaitu suatu proses menuju kehidupan.

\section{Air Baptisan}

Tradisi liturgi Kristen menggunakan air sebagai simbol yang memiliki makna sentral dalam kehidupan umat. Air yang dipakai sebagai media untuk melaksanakan baptisan itu memiliki makna penyucian, kehidupan, dan keselamatan. Setiap orang Kristen yang memberi diri untuk menerima air baptisan, secara simbolis menunjukkan kesediaannya untuk mengalami persekutuan dengan Allah yang menyucikan, menyelamatkan, dan menghidupkan. Di sini, air baptisan merupakan simbol yang kelihatan dan dapat dirasakan oleh orang Kristen yang mendukung pengalaman ragawi sekaligus pengalaman imani mereka tentang hadirat Allah.

Sebagai tanda persekutuan dengan Allah yang menghidupkan, air baptisan juga dapat dimaknai dari realitas tubuh perempuan. Berdasarkan pengalamannya sebagai seorang perempuan, ibu, dan pastor, Berger menunjukkan keterkaitan erat antara air ketuban dan air baptisan sebagai aliran air kehidupan. Ketika melayankan baptisan bagi anaknya sendiri, air baptisan yang ia sentuh itu menyadarkannya 
tentang makna Allah sebagai air hidup. Bagi Berger, ada kemiripan yang sangat kuat antara air ketuban dan air baptisan. Air ketuban dan air baptisan merupakan bagian penting dari momen menuju kehidupan. Di dalam kedua momen yang sangat penting ini, yaitu pecah air ketuban dan percik air baptisan, Allah Sang Sumber Hidup menjadi tampak jelas. Ia yang membukakan jalan kehidupan bagi setiap orang dan membawanya pada jalan kehidupan. ${ }^{19}$

Pemikiran Berger ini menarik. Dari penuturannya tampak bahwa batasan antara momen kelahiran dan momen baptisan menjadi sangat tipis, begitu pula batasan antara air ketuban dan air baptisan. Kedua peristiwa penting dalam kehidupan setiap orang Kristen ini mestinya dirangkul secara liturgis untuk mengenal dan memahami serta mengalami pemeliharaan Allah dalam kehidupan umat. ${ }^{20}$

Ruether juga memberi pemaknaan khusus tentang air sebagai simbol penting dari liturgi baptisan. Menurutnya, air yang dituangkan ke atas kepala secara simbolis menegaskan pembersihan dan pemulihan orang yang menerimanya. Orang tersebut dibersihkan dan dimurnikan dari pengaruh-pengaruh buruk kuasa kejahatan yang berwujud dalam kekerasan dan ketidakadilan. Ia menawarkan rumusan yang bertujuan menguatkan orang yang menerima air tersebut:

"Through the power of the Source, the liberating Spirit and the forerunners of our hope, be freed from the power of evil. May the forces of violence, of injustice and of all that diminishes human life lose their power over your life. May all the influences of these powers be washed away in this purifying waters. May you enter the promised land of milk and honey and grow in virtue, strength, and truthfulness of mind." 21

Dalam rangka ritus pemulihan, selain rumusan kata penguatan, Ruether juga menawarkan penggunaan simbol air hangat yang dicampur dengan daun atau bunga dengan aroma yang tidak saja harum, tetapi juga membawa efek relaks dan tenang. Air tersebut dapat digunakan untuk membasuh tubuh perempuan korban/penyintas kekerasan seksual. ${ }^{22}$ 
Contoh pemaknaan atas simbol air baptisan yang diutarakan di atas, dapat dipakai untuk mengklaim kembali makna air bagi perempuan korban/penyintas KT. Air baptisan yang dituangkan ke atas kepala secara simbolis menegaskan penganugerahan kuasa Allah Sang Roh dan Sumber Kehidupan yang membebaskan dan membawa harapan. Air itu juga secara simbolis menghapus dan menghilangkan pengaruh dari praktik kejahatan, pemaksaan, dan kekerasan di masa lalu, serta semua hal yang menimbulkan trauma atas diri perempuan. Air itu secara simbolis menegaskan keberadaan perempuan yang memasuki tanah perjanjian yang penuh susu dan madu dengan keyakinan, kekuatan, pengharapan, dan sukacita yang baru. ${ }^{23}$

Dari percakapan tentang air sebagai media baptisan tersebut, umat dapat mengimajinasikan suatu ritual gerejawi sebagai bagian dari liturgi kehidupan berbasis pengalaman konkret perempuan korban KT. Dengan menggunakan simbol air, umat mengklaim ulang pengalaman akan air baptisan sebagai pengalaman perjumpaan perempuan dengan Allah yang membebaskan, menghidupkan, dan menyelamatkan. Simbol air yang digunakan merupakan penanda dari pengalaman berbalik arah (metanoia) dalam rangka pembebasan dan transformasi yang merupakan aspek penting bagi para penyintas kekerasan seksual.

Sebagaimana telah diuraikan di atas, pengalaman perempuan korban KT sehubungan dengan air adalah pengalaman yang traumatis. Air telah dipakai oleh pelaku KT sebagai simbol kekerasan, pemaksaan, dan penaklukan. Melalui pemaknaan khusus atas air baptisan, maka perempuan mengingat dan mengklaim kembali kekuatannya yang berasal dari kasih karunia Allah untuk memutus rantai pengasingan dan penindasan KT. Air baptisan merupakan simbol yang kelihatan yang dapat dipakai oleh perempuan korban KT untuk bangkit dan berbalik arah dari pengalaman traumatis di masa lalu, ke kehidupan baru masa kini yang penuh harapan. Komunitas beriman menjadi saksi dan turut serta mendukung tindakan berbalik arah tersebut.

\section{Gereja sebagai Komunitas yang Memberdayakan}

Kehadiran gereja sebagai komunitas pendukung menjadi penting bagi perempuan korban/penyintas KT. Ruether menyebutnya sebagai komunitas feminis 
yaitu persekutuan laki-laki dan perempuan yang saling mendukung, memberdayakan, dan membebaskan. Komunitas itu ditandai oleh model bergereja sebagai komunitas exodus dari patriarki yaitu suatu komunitas yang melepaskan diri dari cara, pola, dan sistem sosial yang menindas. Dengan mengusung visi pembebasan, komunitas ini memahami simbol-simbol sakramental primer seperti baptisan dan ekaristi secara baru dan menghubungkannya dengan pengalaman nyata umat beriman terutama pengalaman perempuan yang selama ini terpinggirkan dan tertindas dalam masyarakat dan institusi gereja. Dalam komunitas ini, pengalaman nyata perempuan termasuk yang berkaitan dengan pengalaman kekerasan seksual dijadikan basis untuk mendesain bentuk-bentuk liturgi kontekstual. ${ }^{24}$ Liturgi tersebut bertujuan untuk memberikan dukungan kepada mereka agar bangkit dari pengalaman traumatis dan berproses mengalami pemulihan.

Gereja sebagai komunitas yang mendukung orang-orang tertindas untuk pembebasan dan transformasi itu, tidak terlepas dari hakikatnya sebagai persekutuan exodus (yang keluar) dari kehidupan lama yang ditandai oleh penderitaan dan penindasan, ke kehidupan baru yang ditandai oleh sukacita dan pengharapan. Gereja pada hakikatnya adalah persekutuan yang dipanggil keluar dari dalam kegelapan menuju terang keselamatan. ${ }^{25}$ Hakikat gereja ini mesti terus dihidupi untuk menjadi komunitas exodus yang bersama-sama perempuan korban/penyintas KT menyatakan tindakan keluar dari berbagai bentuk penindasan menuju kehidupan dan keselamatan. Tindakan itu secara simbolis dilakukan melalui ritual.

Perspektif feminis-liturgis yang diutarakan oleh Berger dan Ruether dapat menjadi dasar bagi upaya imajinatif komunitas beriman dalam rangka menciptakan ruang ritual gerejawi yang berpihak pada perempuan korban kekerasan seksual. Secara khusus berkaitan dengan pengalaman perempuan korban/penyintas KT, ritual yang dikemas dengan menggunakan media air, didasarkan pada pemaknaan baru atas air baptisan untuk mengklaim kembali simbol iman ini berdasarkan pengalaman khas ketertindasan mereka.

Peran komunitas pendukung bagi perempuan korban/penyintas KT dapat dinyatakan secara konkret melalui ucapan dan tindakan liturgis. Tindakan komunitas 
mengitari, berjalan bersama, menatap, mendengarkan, menyentuh, merangkul, memercikkan air, memandikan perempuan korban/penyintas merupakan wujud dari tindakan dukungan tersebut. Begitu pula dengan ucapan-ucapan liturgis yang diperdengarkan yang bertujuan mengapresiasi, menguatkan dan meneguhkan para korban/penyintas. Ruether menunjukkan contoh:

"In the power of Holy Wisdom, we join together to be strength and protection for each other. Let that power and strength flow from hand to hand, from touch to touch, glance to glance, word to word. Let us bind up the wounds of this house and each other's wounds. Peace and love be with us all, every one." 26

Pengalaman ibadah yang otentik itu muncul dari pengalaman mengutarakan dan mendengarkan narasi orang yang tertindas. Liturgi yang berangkat dari pengalaman konkret perempuan yang tertindas akan memunculkan kata-kata, tindakan, dan simbol-simbol baru sebagai bentuk interaksi dengan simbol iman. ${ }^{27}$ Komunitas beriman akan mengalami ibadah yang otentik ketika mendengarkan narasi perempuan korban/penyintas KT dan bersama mereka melakukan tindakan metanoia dan konversi.

\section{Ritual Percik Air}

Komunitas beriman mesti menjadi komunitas yang berpihak pada korban kekerasan seksual KT. Keberpihakan itu dapat ditunjukkan melalui ruang-ruang liturgis yang diciptakan secara sengaja dan terencana, untuk menjadi ruang yang mendukung pemulihan perempuan korban kekerasan. Ruang liturgis itu merupakan ruang di mana perempuan dapat mengingat kembali dan mengekspresikan pengalaman kepahitan di masa lalu. Kemudian dengan menggunakan simbol-simbol tertentu dan didukung oleh komunitas yang bersamanya, ia mengklaim kembali kebebasan dirinya. ${ }^{28}$

Salah satu cara yang dapat ditempuh oleh perempuan dan komunitas beriman untuk mengalami momen pembebasan adalah dengan melakukan Ritual Percik Air (selanjutnya RPA). Ritual ini secara khusus didesain dengan menggunakan media air 
sebagai simbol yang sarat makna. Air adalah simbol kesegaran, kemurnian, dan kehidupan. Dalam baptisan, air secara simbolis merupakan jalan menuju kelahiran baru, kehidupan, dan keselamatan. Selain itu, air juga merupakan simbol berdimensi sakral yang sangat dekat bahkan menyatu dengan pengalaman perempuan. Ketika dalam praktik KT, air dipakai sebagai benda magis yang melemahkan, mendiamkan, dan "mendinginkan" perempuan, maka dalam RPA ini, air diklaim kembali fungsi hakikinya bagi manusia yaitu sebagai simbol yang menyegarkan, menguatkan, menghidupkan, dan menyelamatkan. RPA sekaligus menjadi tindakan liturgis yang hendak memberikan dukungan spiritual bagi perempuan korban/penyintas KT untuk melakukan tindakan metanoia dan konversi. Dengan menggunakan simbol air, ritual ini menjadi tindakan liturgi feminis yang bermakna pemulihan dan pembebasan bagi perempuan korban/penyintas KT.

Dengan diinspirasi oleh model ritual pemulihan korban permerkosaan yang ditawarkan Ruether, ${ }^{29}$ RPA ini dapat dipraktikkan sebagai berikut. Komunitas berkumpul membentuk lingkaran dan perempuan korban/penyintas KT berada di dalam lingkaran tersebut. Seorang anggota komunitas (Liturgos/L1) berbicara menyatakan maksud mereka berkumpul yaitu karena salah satu saudari mereka (bisa menyebutkan nama/N) mengalami kekerasan KT dan bahwa kekerasan itu telah menyebabkan tubuh, jiwa, dan roh saudari $\mathrm{N}$ terluka. Semua yang berkumpul turut merasa terluka, sedih, dan marah atas kejadian itu. Semua berduka karena tidak tahu kapan kekerasan KT akan berakhir dan bagaimana memperbaiki kerusakan yang diakibatkan oleh KT itu. Sekalipun berduka, semua yang hadir menolak untuk menyerah, mundur, dan takut. Semua tetap berjuang untuk pembebasan.

L2 lanjut bicara untuk menegaskan bahwa semua yang berkumpul dalam lingkaran itu mengasihi dan menguatkan saudari mereka $(\mathrm{N})$ yang telah terluka. Sekalipun N terluka, ia tidak hancur. Sekalipun ia direndahkan, ia tidak kehilangan integritasnya. Semua yang hadir meneguhkan keutuhan, kebaikan, kejujuran, integritas, dan kecantikannya. Semua yang hadir sepakat mengusir kekuatan teror, kehancuran, keburukan, kekerasan, dan kebohongan yang menyebabkan $\mathrm{N}$ menjadi korban KT. 
Setelah L1 dan L2 berbicara, korban/penyintas (N) dapat memberikan respons dengan berbicara mengungkapkan pengalamannya, atau dengan tetap diam/hening, atau melalui ekspresi lain yang ia ingin lakukan. Setelah itu, ia mendekat ke bejana atau wadah khusus berisi air yang telah disiapkan oleh komunitas. Wadah atau bejana berisi air itu dapat diletakkan di tengah komunitas. Air itu bisa dicampur dengan aroma tertentu yang disukai oleh N. Ia mengambil air itu, lalu memercikkan ke wajahnya, atau memercikkan di kepalanya, atau dengan jari ia menyentuh air tersebut lalu membentuk tanda salib di keningnya. Bisa juga seorang anggota komunitas (L4) membantu melakukan peran memercikkan air itu ke wajah, kepala, dan tubuh $\mathrm{N}$.

Setelah itu masih dalam lingkaran, seorang perempuan anggota komunitas (L5) maju mendekati N. Dengan tangan menyentuh bagian perut $\mathrm{N}$, ia berkata: "Engkau pulih atas kekerasan yang menimpa tubuhmu". Umat mengaminkan dengan berkata: "Engkau pulih". Dengan tangan menyentuh dada N, ia berkata: "Engkau pulih atas kekerasan yang menimpa mental dan perasaanmu”. Umat mengaminkan dengan berkata: "Engkau pulih". Dengan tangan menyentuh kening N, ia berkata: "Engkau pulih atas kekerasan yang menimpa pikiran dan jiwamu". Umat mengaminkan dengan berkata: "Engkau pulih". Lalu semua yang hadir bersamasama mengucapkan berkat atas N: "Allah Sang Sumber Hidup membelai, mengasihi, dan memelukmu. Berkat-Nya tercurah berlimpah-limpah atasmu, mengelilingimu, menaungimu, mengalir di sekitarmu, menguatkanmu, dan membuatmu menjadi utuh kembali. Amin".

RPA diakhiri dengan memberikan pelukan bagi $\mathrm{N}$, atau mengalungkan tenunan stola berwarna putih dengan motif mamuli berwarna merah atau kuning keemasan. Warna putih dalam tradisi liturgi gereja dipakai sebagai simbol kelahiran dan kehidupan baru. Sedangkan tenunan dan mamuli secara simbolis-kontekstual merupakan klaim kembali atas simbol feminin yang menyatu dengan tubuh dan pengalaman perempuan. RPA bisa juga diakhiri dengan pekikan payawau dan kakalaka sebagai ekspresi sukacita (tentang pekikan ini, N sebelumnya bisa dimintai pendapat apakah setuju atau tidak, mengingat teriakan ini mengiringi prosesi penangkapan yang dialaminya). Jika $\mathrm{N}$ setuju, pekikan itu merupakan 
tindakan klaim kembali atas sorak-sorai khas Sumba dengan pemaknaan baru yaitu sukacita karena pemulihan yang dialami N. Semua yang hadir bisa menari bersama N. RPA bisa juga diakhiri dengan jamuan makan dan minum bersama. Dalam tradisi liturgi gereja, baptisan dirangkaikan dengan perjamuan kudus/ekaristi. Komunitas dapat menyiapkan makanan dan minuman yang disukai $\mathrm{N}$ dan menikmatinya bersama-sama.

\section{KESIMPULAN}

Imajinasi liturgi feminis berbasis pengalaman nyata perempuan yang tertindas bertujuan untuk pembebasan dan pemulihan. Ketika gereja mendengarkan pengalaman perempuan korban/penyintas KT dan secara sadar mengintegrasikannya ke dalam ritual gerejawi, maka gereja telah menjadi komunitas feminis yang bersama perempuan korban/penyintas KT melakukan tindakan metanoia dan konversi menuju kehidupan yang sesungguhnya.

\section{Endnotes}

\footnotetext{
${ }^{1}$ Aprissa Taranau, "Menggugat Praktik Kawin Tangkap Dalam Budaya Perkawinan Di Waikabubak, Sumba Barat, NTT," in Perdamaian Dan Keadilan: Dalam Konteks Indonesia Yang Multikultural Dan Beragam Tradisi Iman (Jakarta: BPK Gunung Mulia, 2017), 204.

${ }^{2}$ Taranau, 204-5.

${ }^{3}$ Oe. H. Kapita, Masyarakat Sumba Dan Adat Istiadatnya (Waingapu: Panitia Penerbit Naskahnaskah Kebudayaan Daerah Sumba, Dewan Penatalayanan Gereja Kristen Sumba., 1976), 125.

${ }^{4}$ Lisa Isherwood and Elizabeth Stuart, Introducing Body Theology (Sheffield: Sheffield Academic Press, 1998), 43-44.

${ }^{5}$ Nggodu Tunggul, Etika Dan Moralitas Dalam Budaya Sumba (Jakarta: Pro Millenio Center, 2004), 59-60.

${ }^{6}$ Tunggul, 26.

${ }^{7}$ Tunggul, 55.

8 Rosemary Radford Ruether, Women-Church: Theology and Practice of Feminist Liturgical Communities (San Fransisco: Harper \& Row, 1985), 87.

${ }^{9}$ Ruether, 125.

${ }^{10}$ Ruether, 125.

${ }^{11}$ Ruether, 126-27.

${ }^{12}$ Ruether, 127-28.

${ }^{13}$ Teresa Berger, Fragments of Real Presence: Liturgical Traditions in the Hands of Women (New York: Crossroad Pub. Co., 2005), 3-6.

${ }^{14}$ Berger, 13-14.
} 


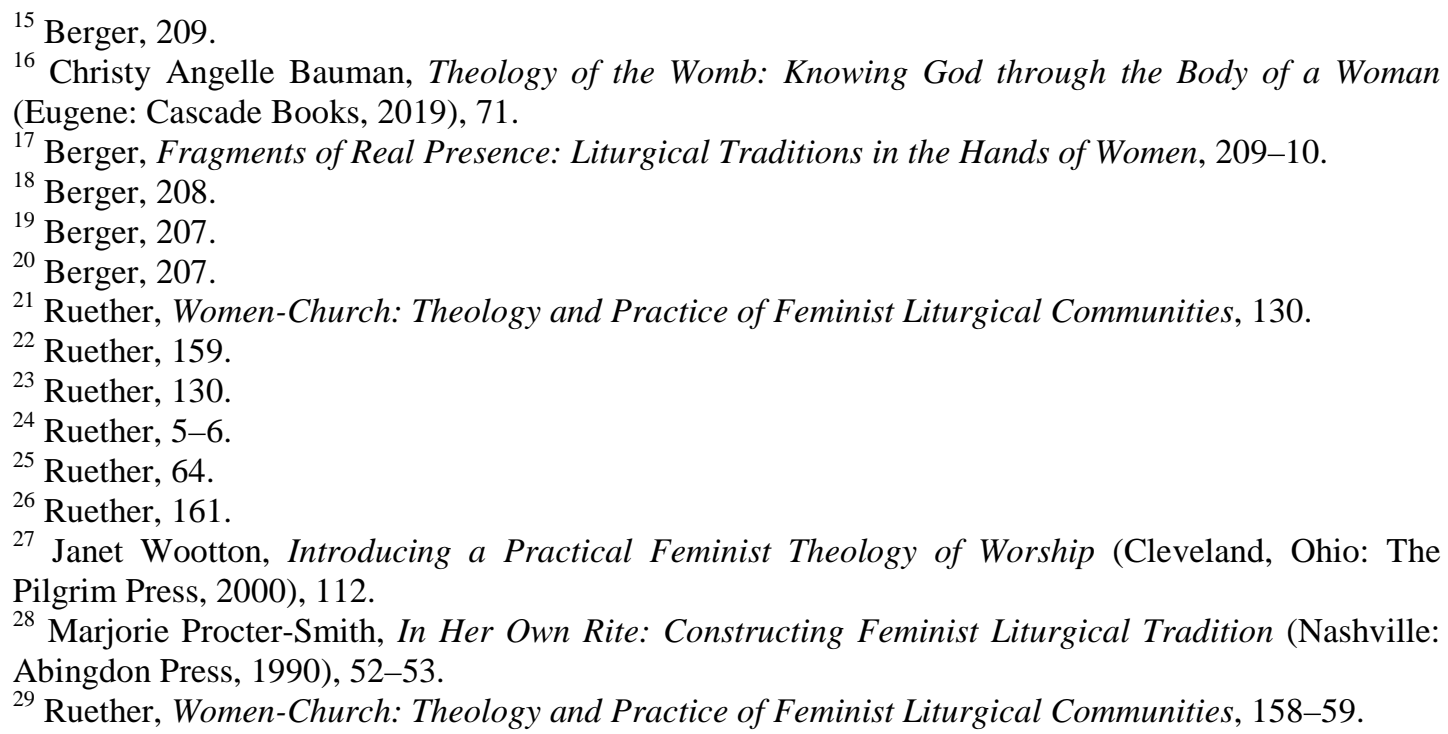

\section{DAFTAR PUSTAKA}

Bauman, Christy Angelle. Theology of the Womb: Knowing God through the Body of a Woman. Eugene: Cascade Books, 2019.

Berger, Teresa. Fragments of Real Presence: Liturgical Traditions in the Hands of Women. New York: Crossroad Pub. Co., 2005.

Isherwood, Lisa, and Elizabeth Stuart. Introducing Body Theology. Sheffield: Sheffield Academic Press, 1998.

Kapita, Oe. H. Masyarakat Sumba Dan Adat Istiadatnya. Waingapu: Panitia Penerbit Naskah-naskah Kebudayaan Daerah Sumba, Dewan Penatalayanan Gereja Kristen Sumba., 1976.

Procter-Smith, Marjorie. In Her Own Rite: Constructing Feminist Liturgical Tradition. Nashville: Abingdon Press, 1990.

Ruether, Rosemary Radford. Women-Church: Theology and Practice of Feminist Liturgical Communities. San Fransisco: Harper \& Row, 1985.

Taranau, Aprissa. "Menggugat Praktik Kawin Tangkap Dalam Budaya Perkawinan Di Waikabubak, Sumba Barat, NTT." In Perdamaian Dan Keadilan: Dalam Konteks Indonesia Yang Multikultural Dan Beragam Tradisi Iman. 
Jakarta: BPK Gunung Mulia, 2017.

Tunggul, Nggodu. Etika Dan Moralitas Dalam Budaya Sumba. Jakarta: Pro Millenio Center, 2004.

Wootton, Janet. Introducing a Practical Feminist Theology of Worship. Cleveland, Ohio: The Pilgrim Press, 2000. 